A Journal of Culture, English Language Teaching \& Literature

ISSN 1412-3320 (Print), ISSN 2502-4914(Online)

Vol. 16 No. 1; July 2016

Copyright (C) Soegijapranata Catholic University, Indonesia

\title{
THE PATTERN OF AMERICAN RHETORIC ON THE SPIRIT OF MISSION: AN ANALYSIS OF THE TEXT OF BUSH'S INAUGURAL ADDRESS
}

\section{Mister Gidion Maru}

English Department, Faculty of Language and Arts, Manado State University, Indonesia

Tel +62 81340075651

Email: mrhekang@yahoo.com

Received: 15-12-2015

Accepted: 14-07-2016

Published: 31-07-2016 


\title{
THE PATTERN OF AMERICAN RHETORIC ON THE SPIRIT OF MISSION: AN ANALYSIS OF THE TEXT OF BUSH'S INAUGURAL ADDRESS
}

\author{
Mister Gidion Maru \\ mrhekang@yahoo.com \\ English Department, Faculty of Language and Arts, \\ Manado State University, Indonesia
}

\begin{abstract}
As a textual study, this research paper aims at elaborating the rhetorical patterns in the American mind by examining the inaugural addresses of George W Bush particularly on the spirit of mission. The choosing of the president's inaugural address as the mental evidences is not apart from the synthesis that it represents a formal speech which covers the socio-cultural aspects and they will bring a certain pattern of rhetoric in their attempt to communicate with the public. For the purpose of achieving the aim of this research, the library research is carried out by applying Goffmans Frame Analysis. The results show that the president constructs a certain pattern of rhetoric by using the Puritan expressions particularly for engaging the American people with the spirit of mission. The rhetoric patterns are found to convey the national and world mission. The expressions used in the inaugural addresses seem to meet with people's expectations as a new presidency begins.
\end{abstract}

Key words: rhetoric, pattern, spirit of mission, inaugural address

Abstrak: Penelitian ini bertujuan mengeloborasi pola retorik dalam pikiran Amerika dengan mempelajari pidato pelantikan Presiden George W Bush terutama berkaitan dengan semangat misi. Pemilihan pidato pelantikan sebagai bukti mental dalam studi ini tidak terpisahkan dari sintesis yang menyatakan bahwa pidato pelantikan mewakili tipikal pidato resmi Amerika yang isinya mencakup aspek sosio-kultural dan pola retorik kepada publik. Sebagai penelitian kepustakaan, studi ini menggunakan frame analysis dari Ervin Goffman dikombinasikan dengan pendekatan sosiologi sastra. Hasil studi menunjukan bahwa 
Maru, M.G., The Pattern of American Rhetoric on the Spirit of Mission: an Analysis of the Text of Bush's Inaugural Address

presiden Bush menggunakan pola retorik yang memanfaatkan ungkapan-ungkapan yang biasa dipakai kaum Puritan di awal berdirinya Amerika. Ekspresi-ekspresi tersebut digunakan sebagai cara untuk menghubungkan publik dengan semangat misi Amerika. Pola retorik itu ditujukan untuk mendefinisikan misi nasional dan internasional Amerika. Pola retorik ini juga dapat mengadopsi harapan publik untuk seorang Presiden yang baru.

Kata kunci: retorik, pola, pidato pelantikan, misi Amerika

\section{INTRODUCTION}

The inaugural speech serves as the first presidential formal speech before his public which is most possibly constructed to adopt the values living in the country. The American presidents' inaugural speeches unavoidably contain American life-rooted socio-cultural values as confirmed by Chyntia Toolin by pointing out:

... in inaugural speech, presidents give their official statement of how they view the national situation, frequently citing a cultural core or civil religion for the legitimation (1983, p. 40).

Grounding upon this perspective, it is not excessive to assume that the aroma of cultural life and perspectives of the American can be detected from the inaugural speech. This implies that by drawing one's eyes upon the text of the presidents' inaugural speeches and considering its tendency as well as momentum, the attempt to comprehend an existing value in American life is on the way to find its goal. Lloyd E. Rohler and Roger Cook describe presidential inaugural speeches in their book Great Speeches (1986):

At moments like these, speakers speech audiences about the values that both share as members of a common group, the speeches given in such moments are thus noncontroversial for a specific audiences. They do not urge adoption of new values or rejection of old values (p. 18).

This proposition reaffirms the propensity of the inaugural speech to take the existing values which are believed and upheld together by both the speaker and audience in the context of the nation. A president as the speaker of the speech mindfully presents the socio-cultural and political issues confronting the current condition of the people. Yet it does not speculatively offers 
unknown values instead of the issues that have been common in the intention to adapt the American people's situation and hope, and to foreshadow the future of the nation.

Through the inaugural speech, the image of a president of a great nation might be viewed from the president's appearance and performance (Woll, 2004, p. 278). The world defines the impressions toward the country from the president' words. This means that, by empowering his speech, the president potentially implant ideas and thoughts to the mind of his people and the international world that he represents the spirit of the United States. As a president stands to express his speech, he reflects the presence of a solution for the national problems and manages to achieve the American dreams. In doing so, as the icon of the nation, the president shares his values and objectives as a nation.

A president, through his speech, reflects the mood of his country and the national voice. According to Woodrow Wilson in Understanding the Presidency (2003) Edited by James Pfiffner and Roger H Davidson, in such case, the president is "the representative of no constituency, but of the whole people (p.34)". In this occasion, He does not belong to a certain group, community or party anymore. He is voicing his people's voice. Woll wrote, "The president has prerogative to speak the people's mind on the great issues of his time, to serve the spokesman for the real sentiment and purpose of the country" (2004, p.277). This informs that a president's inaugural speech might contain the thought of the American people in responding to the situation as summarized by the president and, of course, guard the nation to arrive at the shared objective and dream. Further, it defines American presidents' speeches to constitute worthy resources for understanding the American mind, socio-cultural and political life. The attempt to define the concepts as well as the type of American cultural values can be carried out by observing and analyzing the inaugural speech of a president.

Thus if the spirit of mission is thought to be one of the cultural cores of American values, its inclusion in a president's inaugural speeches becomes possible and detectable. It is further theorized that Fredrik Merk (1963) for America, "A truer expression of the national spirit was a mission. This was present from the beginning of American history, and is present clearly today" (P.26). This proposition implies that missionary mindset occupies American people crossing generations. It has been a value accompanying America society since the early foundation of the nation. Basing upon this assumption, it is logical to investigate the concept of the spirit of American 
Maru, M.G., The Pattern of American Rhetoric on the Spirit of Mission: an Analysis of the Text of Bush's Inaugural Address

mission. They deserve to be examined in depth. If the spirit of American mission is part of a society belief from generation to generation, this study will, then, reveal the dynamic of the society, and further the conceptual meaning and type of the existing socio-cultural values.

The other reason for choosing of the focus on the speeches of George W. Bush is not for the situation during the Bush administration. At the time, America were faced with the test of terrorism and the launch of foreign policy on war which questioned the concept of the American mission.

In this context, this study aims at identifying the contemporary concept of the spirit of mission and defining the American mind as reflected in the President Bush's inaugural speeches. The identification of the concept constitutes the systematic attempt to reveal the meaning of the American mission and the understanding of the cultural awareness of the American people.

\section{METHOD}

The primary data of this research are the texts of Bush's inaugural speech serving as mental evidences to answer the objective of the study. The secondary, or supplementary, data is taken from related sources in the forms of documents, commentaries, opinions, testimonies and biographies from libraries and journals as well as online data found on the internet. This sort of data is gathered in the frame of interdisciplinary perspective meaning that the supplementary data collected grounding on the consideration of enhancing theoretical knowledge from anthropological, social, political and historical. The supplementary data assist the researcher's formulation and analysis of the primary data which, in turn, arrive at the objective of the study. This research is conducted in the light of two phases namely data collection and data analysis.

In terms of data analysis, the focus of this study is on the identification of the concept the American mission. Three steps are taken in dealing with the data collected; namely identification, classification and verification. The steps involved the use of the literary approaches such as sociological approach and frame analysis. This means that the analysis demands the inclusion of socio-political, anthropological and historical views. 


\section{DISCUSSION}

Fredrik Merk (1963) wrote, for America, "A truer expression of the national spirit was a mission. This was present from the beginning of American history, and is present clearly today" (P.26). This proposition implies the sense of mission colors the thought of most of the American individuals. The conduction of Goffman's Frame analysis which is so-called double-hermeneutic on the presidential inaugural address, particularly for George W. Bush's, comes to find the tendency of the president is to integrate the nation with the strong sense of mission. In this context, the Puritans' sense of mission that has been chipped-in the people's mind could function to aggregate people's acceptance to the president and draw people's awareness to advocate the policies drafted by the new administration. The presidents by taking Puritanism, as Goffman argued, "present themselves in the ways to influence people" (Hinkley, 1990, p.130). In terms of the inaugural address, it could mean that the inclusion of the Puritanism' sense of mission in the text of an inaugural address indicates the president is presenting himself in a hope of influencing his people to have the same focus as him. In light of such perspective, President George W. Bush in the line of his first inaugural address uttered,

Sometimes in life we are called to do great things. But as a saint of our times has said, 'every day we are called to do small things with great love'. The most important tasks of a democracy are done by everyone." (1 Bush line 39)

President Bush seems to attractively use the puritans' conceptual terminology of 'saint' and 'calling' in suggesting the sense of a mission. By comparing the nuance of 'sometimes in life' to 'but as a saint of our times...we are called to do", the president defines the obligation for American. He urged that every individual has to be the saint of this time; "visible saints" (Ahsltrom, 1967, p.2, Bercovitch, 1978, p.12), within which everybody is connected with the sense of performing certain civic duty and is closely tied to the sense of a mission. President Bush portrays the sense of mission which he emphasizes as 'the most important task' for Americans. This suggests that, as an American, a citizen recalls and carries out the missionary task.

\section{A. The Rhetoric of American Mission for National Interest}

George Walker Bush, the president after the Clinton administration, continues to juxtapose the national mission with the "unfolding American promise' for which Americans "are called to enact". For Bush, in his first 
Maru, M.G., The Pattern of American Rhetoric on the Spirit of Mission: an Analysis of the Text of Bush's Inaugural Address

inaugural address, the core of American promise is that "everyone deserves a chance" (line 7). This implies the availability of opportunity for all. It is typical for "the promised land". Bush's address highlights the idea of American promise that syntheisized the same availability of opportunity for all people in America. Since the Americans tie to the promise, the mission shall be acted out. This is implicitly spoken in the following lines;

The grandest of these ideals is an unfolding American promise that everyone belongs, that everyone deserves a chance, that no insignificant person was ever born.

Americans are called to enact this promise in our lives and in our laws. And though our nation has sometimes halted, and sometimes delayed, we must follow no other course. (1 Bush line 7-8)

These expressions are politically remarkable. President Bush portrays the expectation that the present Americans are hoped to act as the Puritan individuals who positioned themselves with a mission to follow god; they should follow the calling of their country. People are pictured in the frame of calling to carry out the American promise as the mission to be completed. Surely, it is admitted that the accomplishment of the mission for the national sake would be uneasy. The challenges may come to hinder the process, yet it was not considered being the justification to leave the mission and ignore the realization of the promise. The journey of the Puritans sailing over the Atlantic with full of huge waves and storms before they stepped onto the American shore was also an uneasy task, however, they did not change their course. Nathaniel Philbrick in his book, Mayflower (2006), delineates from the beginning, the pilgrims, another group of Puritans, exhibited all the strength and weaknesses of a group held together by "a most strict and sacred bond" (p.17) that is when circumstance turned against them, these Puritans demonstrated remarkable courage and endurance; indeed, adversity seemed to intensify their clannish commitment. They are covenanted and committed to the mission to reach the New World to find freedom and better hope. The coming of obstacles has to be beheld; it is the part of the mission to be conquered. Therefore, in the invitation from Bush to the Americans to "follow no other course", the mission is demanded to be fulfilled. The challenge might even shape the strength of America in defending its existence. Bush, like Winthrop, the early Puritan leaders, employs his inaugural address to exhort Americans "to knit together into a social security that reflects and supports their spiritual unity" which 
guarantees the direction of the mission. The tests of the country are inevitable, yet as long as the people are in unity, the mission will be accomplished. This reinforces the perspective imbued by Winthrop in his sermonic address in Arbella that, according to Deborah Madsen, politically, "the federal covenant would work only so long as all members of the community voluntarily kept their faith and helped others to preserve faith (1998, p.18). In this context, it is little modified to be the faith to preserve of American sense of mission to contribute a political support for the government. Likewise Winthrop in the time of Puritans suggesting the enactment of the sense of mission based upon "the regulated by law of nature", innocence, and "law of grace", one body in Christ' (Madsen,1998,p.18), Bush at present voices the performance of the totality of the mission for people who "are called to enact it". This rhetoric is politically significant for commencing a new administration. People are drawn to be in the mission for the reason of the national commitment and spiritual interest.

In his second inaugural address, President George W. Bush continues his elaboration of the American Mission by drawing it back to the values that have been introduced and spread since the arrival of the Puritans. These include equality of rights, which was translated as the freedom for religious practice, and implicit government which marked by the magistrate meeting foreshadowing the independence from the influence of the Old World, England. This constitutes the legacy of the Puritans (Corbett and Corbett, 1999, p.38) that contributes to the groundwork for democracy in America. It has penetrated generation to generation. Hence, it is not surprising that the values have been fundamental and inseparable from the American national mission as it is indicated in the following lines;

America's vital interests and our deepest beliefs are now one. From the day of our Founding, we have proclaimed that every man and woman on this earth has rights, and dignity, and matchless value, because they bear the image of the Maker of Heaven and earth. Across the generations we have proclaimed the imperative of self-government, because no one is fit to be a master, and no one deserves to be a slave. Advancing these ideals is the mission that created our Nation. It is the honorable achievement of our fathers. Now it is the urgent requirement of our nation's security, and the calling of our time. (2 Bush line 6) 
Maru, M.G., The Pattern of American Rhetoric on the Spirit of Mission: an Analysis of the Text of Bush's Inaugural Address

This quotation clarifies that defending and maintaining the values of equality and independent government which serves the public interest and opportunity. It is "advancing these ideals" that became the ingredients that defines the mission of the nation. It is the triumph of the founding fathers. That means any challenges to the nation were assumed to be the attack to these across generation-values and had to be dealt with. In this part of the address, it appears that President Bush invites his people to partake in the attempt to eliminate the challenge that faces "national security" through associating it with the Puritans' notion of calling. The calling is addressed to everyone who sees this attack and urges them to uphold the national mission in existence. Todd S Purdum from New York Times points out that President Bush began his second terms without uttering September 11 or terrorism for the purpose of allowing him to cast the crises and controversies of his first four years and the ones he welcomes in the next mission in defense of the nation's founding creed; freedom (New York Times, January 21, 2005). Bush seals his people with a missionary zeal like the Puritan individual. He frames Americans to see themselves amidst the mission to support the urgency of copying with the threats to the continuation of the country. It is the "calling of our time". Bush links American public to the long time belief passed down from the Puritan settlers that they have a calling to shape and witness the betterment of the community in the narrow scope. The calling might vary for every American citizen in every era. However, like the Puritans, the essential of the calling remains the same for American that "strove not to please himself" (Cullen, 1974, p.408). The calling is carried out for the existence of the community, in this case, the nation and surely, as Bush underlined, to God who is "the Maker of heaven and Earth". Mr Bush draws his people to an image that they are answering a calling for whom is imposed the responsibility to preserve and maintain the existence of the nation, moreover, at this time when the country's security is in the middle of terror as marked by the $9 / 11$ attack. These terrorist attacks strengthen the context of Bush's words. In light of this, Bush further affirms,

My most solemn duty is to protect this nation and its people from further attacks and emerging threats. Some have unwisely chosen to test America's resolve, and have found it firm. (2 Bush line 10)

This affirmation indicates that responding to the attack to his countries security is one of the national missions to carry. For Bush, to guarantee his people to be free from the threats constituted his duty as the leader of the nation. By taking up the Puritans' notion of duty which is of course related 
to the performing of mission and responsibility under the big picture of a calling, the declaration of Bush's "solemn duty" politically illustrates the ground for the possibility to launch the possible action toward any menaces intended to the nation. It serves as a sort of political reasoning to invite the people's support for what he defines as the duty of the nation. It is the task that is needed to be carried out. Using his inaugural address and the Puritans' concept, Bush voices that the nation is asking Americans to be hand in hand with the government to defend their coexistence. It is apparent that Bush presents the American public with the situation faced with their nation, linking them with the Puritan's missionary vision. For such a purpose, Bush claims to be the first example by referring to intention to lead the duty of guarding the nation's security in all forms and fronts. Here Bush designs, provides, and frames the justification for his later domestic political agenda. Nation is insecure and is in need of proper acts as well as in expectation of people's support. These confirm the mission that every American is pushed to accomplish by the Bush administration.

\section{B. The Rhetoric of the American World Mission}

Having a sense of a world mission has been the feature of America since its early settlement. The well-known address spoken by the Puritan leader, John Winthrop, has declared the intention on inspiring the world by his famous expression; "the eyes of the world are upon us" which conveys the message of America as a focus of the world from which it gains its definition of mission; to be the model for the world. Americans, taking up the Puritan's heritage, are required to work for the goodness of all, in Puritans' words, "for the entire community" (Madsen, 1998, p.6). This is translated to carrying out the mission for the betterment of the world as a whole. Being the focus of the eyes of the world implies the duty to enact a mission to show the world an example from which the inspiration for better life sparks. The sense of mission energizes and characterizes the making of America as well as the journey of America to a modern nation. The sense of mission is actually rooted in Puritanism. The idea that everyone has a mission is brought by the Puritans to suggest the attempt to spread the Good News of Salvation. This Puritanism sense of mission continues to shape the American mind including the conduction of a world mission related to the Calvinistic view of the duty of the chosen people who "shall be a city upon a hill" as voiced by Winthrop. It becomes the attribute of American vision for the world's coexistence. This serves as a kind of Puritan moralistic view. Steven Calabresi (2006) perceived that America's Puritan moralistic crusade improves the fallen world by presenting that the American's achievement is not apart from 
Maru, M.G., The Pattern of American Rhetoric on the Spirit of Mission: an Analysis of the Text of Bush's Inaugural Address

this spirit. For Calabresi, such sense of Puritanism describes "a missionary dimension to American life and policy" (2006, p.1366). The dimension, of course, colors Americans' standpoint to the world interaction and affairs; it is a missionary duty.

The American world mission is then stressed as well as reminded by President George W Bush, in his inaugural address. Recalling Bush senior's address, the American mission for the world exists due to the fact that America cannot stand in isolation from the rest of the world. However the coexistence has to be grounded upon reliable moral basic. This is a kind of Puritan mind of establishing the community based upon the strict moral standard as recommended by biblical teachings. It is American duty to set the standard for their exceptional existence as a model for the world. In other words, it is true that America is not alone in the world, yet its relationship to other nations must have been under the moral criteria believed by the Americans and served to be the aim to be achieved. The following words might reflect such point of view;

America is never wholly herself unless she is engaged in high moral principle. We as a people have such a purpose today. It is to make kinder the face of the Nation and gentler the face of the world. My friends, we have work to do. There are the homeless, lost and roaming. There are the children who have nothing, no love, no normalcy. There are those who cannot free themselves of enslavement to whatever addiction-drugs, welfare, the demoralization that rules the slums. There is crime to be conquered, the rough crime of the streets. There are young women to be helped who are about to become mothers of children they can't care for and might not love. They need our care, our guidance, and our education, though we bless them for choosing life (G. Bush line 13)

Apparently, these lines articulate the core of the American mission. The mission for the world is to bridge a better world within which the children are well-taken care, the drugs addiction is fought, the welfare and demoralization in the slums are mainly concerned, crime is prevented, and powerless young mothers are given necessary assistance including care, education and guidance as well. These are substances of the American mission for the world in Bush administration. The circumstance slightly modifies Bush's political mission for the world. The end of the cold war does not cease the tendency of America's participation in world affairs. President 
Bush signals that his administration may take a necessary action to guarantee the American role to set a standard of peace and liberty for the world.

The president here is put forward the tendency to have a role to establish peaceful communities without oppression as once dreamed by the early American Puritan settlers as they left their Old World. They were persecuted for their beliefs and far from being saved and peaceful. The Iraq oppression may be viewed as the hindrance for the establishment of a better community which had been long launched by the early American settlers Bush is bringing the idea of a world mission conducted under the umbrella of making the community living in a peaceful life; no oppression and full of freedom.

Similar propensity of participating in the world mission is taken by President George W Bush. The intention to flourish the world with the spirit of liberty and set a model as it continues to color the lines of the succeeding the American President's inaugural address. In his second inaugural address, Bush states,

Some, I know, have questioned the global appeal of libertythough this time in history, four decades defined by the swiftest advance of freedom ever seen, is an odd time for doubt. Americans, of all people, should never be surprised by the power of our ideals. Eventually, the call of freedom comes to every mind and every soul. We do not accept the existence of permanent tyranny because we do not accept the possibility of permanent slavery. Liberty will come to those who love it. (2 Bush line 13)

From the text, it is seen that President George W. Bush highlights that some people might be doubtful as to the world desire for liberty. However, for American, it is, like in the Puritan perspective, the calling that needs to be answered. Elisabeth Bummiler and Richard W. Stevenson in their collaborative article in the New York Times wrote that Bush's inaugural address obviously strikes for its idealism that spreading liberty around was 'the calling of our time' and that the nation's 'vital interest and our deepest belief are now one" (New York Times, January 21, 2005). This indicates that the world mission, for Bush, is chiefly in the sense of enacting the calling to bring liberty to the world. Like the Puritans, President Bush pictures it as a calling for American; a duty to divine purpose. This calling "comes to every mind and every soul". The implication furthermore is that America will initiate the advocacy to all of the attempts to eradicate tyranny as once 
Maru, M.G., The Pattern of American Rhetoric on the Spirit of Mission: an Analysis of the Text of Bush's Inaugural Address

experience by their ancestor in the Old World. Tyranny cannot be accepted. It constitutes an irresistible duty for America when it is questioned in other nation. That will be an arena for America to show its calling. President George W. Bush elaborates such thought by stating,

A few Americans have accepted the hardest duties in this causein the quiet work of intelligence and diplomacy ... the idealistic work of helping raise up free governments ... the dangerous and necessary work of fighting our enemies. Some have shown their devotion to our country in deaths that honored their whole lives-and we will always honor their names and their sacrifice. (2 Bush line 22)

Since the world mission is considered as a puritanical calling, it is consequently bringing the demand for active participation despite the raise of the perils. It is true that Bush does not mention explicitly "our enemies". However, the omission appears to be the point; allowing the president "to cast crises and controversies" related to the issue of Iraq, Afghanistan, Sept 11 or terrorism of his previous administration". Bush leads to the essential message of his second presidency to welcome "a seamless struggle in defense of the nation's founding creed; freedom" (Purdum, New York Times, January 21, 2005). This implicitly depicts Bush's assumption that his foreign policy toward "the enemies" might be misunderstood and misjudged by his fellow citizens. In so doing, Bush connects the American people to the nation fundamental creed of gaining and preserving liberty, and, most importantly, juxtaposes them to the Puritan divine duty that namely answering "the calling of our time". George Walker Bush obtains an opportunity to reset people's possible misunderstanding which is crucial for his political legitimization and support. There can be two ways of arranging the mission, as the lines indicated. Firstly, it might be carried out thorough the work of intelligence operation. Secondly, it would be voiced through diplomacy. Of course, these efforts would not be an easy task to perform. The sacrifice is possibly unavoidable; "devotion to our country in deaths". From Bush's perspective as affirmed in the lines of the inaugural address, it confirms heroic deeds that will be remembered and honored for it was done "for fighting the enemies" and "helping raise up free government". It is kind of dedication to the enactment of the calling whose values of commitment derived from the Puritan mind; it is a duty that had to be responded for the better community of the world. In a relevant context, Bush, in the text of his inaugural address, continues to assert, 
America has need of idealism and courage, because we have essential work at home-the unfinished work of American freedom. In a world moving toward liberty, we are determined to show the meaning and promise of liberty. (2 Bush line 24)

The text implies that it is the American role expected to carry out the world mission for the purpose of accelerating the liberty of the world. Bush seems to cast "the worldwide pursuit of liberty and democracy as more than rhetoric; it had become a mission" (Hamilton, 2010, p.392). In other words, it is a missionary duty for America to spread the freedom for all as once declared in Winthrop's speech, to be the example for the world in creating a better community. This signifies that George Walker Bush, the president of the big nation, which just suffers from the terrorist attack of $9 / 11$, frames the intention to the world mission of guaranteeing the freedom from fear; one of the essential meanings of liberty and what freedom offers. Further, it clarifies the color of the American policy in the context of a world mission, particularly in the Bush administration. The search for Osama bin Laden who is mainly suspected for designing the $9 / 11$ attack became the main ingredient for American policy for foreign affair as pictured by the issue of Patriot Act which characterized "The War on Terror" policy. According to Hamilton (2010), most of Patriot Act is due to expire at the end of 2005. The president can, however, "express his desire to continue it and perhaps expands its reach" (p.389). This hints the reasoning for Bush to key his people in with the aspect of Puritans' calling in the mission for freedom including freedom from fear of terror. Hamilton further explains that Bush's war on terror leads to the proclamation of the Bush doctrine which is summarized into two important elements;

... first, the United States would wage preventive war against any group or country that threatened American interest, and it would maintain military supremacy by preventing any other nation from emerging its rival (2010, p.389).

The point is that Bush attempts to include the sense of mission by putting the vision of seeking and guaranteeing liberty by borrowing the Puritans' ideals that the vission constitutes "the calling of our time". This can be interpreted as Bush's effort to give the moral foundation to his doctrines to for the American foreign policy. In other words, through Puritan words, Bush finds the ground for the American world mission related to the war on terror in terms of its historical experience and invitation to people's participation. 
Maru, M.G., The Pattern of American Rhetoric on the Spirit of Mission: an Analysis of the Text of Bush's Inaugural Address

\section{CONCLUSION}

American presidents define the exigency of the American public to get involved in the national mission by keying their people with typical Puritan terms such as calling, duty and mission itself. These attempts hermeneutically portray the sense of the American mission in the frame of a Puritanism lense which serves to support the presidents commence and successfully launch the new administration.

In addition, Puritans' notion of setting in the New World, as a city upon a hill as voiced by the leader, John Winthrop, remains echoes in the voice of the present American leaders as reflected in Bush's inaugural addresses. The ingredient of American world mission of the contemporary presidents seems to recalls such Puritan ideals as marked by the employment of terms like mission, calling, and duty. Within the inaugural addresses, the President tends to use the Puritans' words to urge their people in advocating the existence and spread of liberty as the substances for their calling and duty in the world affairs for America and the invitation to participate in the mission.

\section{REFERENCES}

Brinkley, A., \& Davis, D. (2004). The American Presidency. New York: Houghton Mifflin Company.

Corbett, M., \& Corbett, J. M. (1999). Politics and Religion in the United States. New York: Garland Publishing Inc.

Hess, S. (2008). What We Do Now? A Book for the President Elect. Washington, D.C.: Brookings Institution Press.

Hinckley, B. (1990). The Symbolic Presidency: How Presidents Portray Themselves. New York: Routledge, Chapman and Hall, Inc.

Lemay, J.A.L (ed). (1988). An Early American Reader. Washington, D.C: United States Information Agency.

Merk, K. (1963). Manifest Destiny and Mission in American History. USA: Harvard University Press.

Nelson, M. (2005). Election and Achievement: Campaigning and Governing in the Reagan Era. In P, Kengor and P. Schweizer (Eds). The Reagan Presidency: Assessing the Man and his Legacy. Larham: Rowman and Littlefield Publisher Inc. 
132 Celt, Volume 16, Number 1, July 2016, pp. 118-132

Nelson, M. \& Rusell L.R. (2010). The President Words: Speeches and Speechwriting in the Modern White House. Kansas: University of Kansas Press.

PBS Hour 2009, January 15. Speechwriters Answered Your Questions on Crafting an Inaugural Address. Retrieved August 28, 2013 from www.pbs.hour.com.

Rohler, L.E, \& Roger, C. (1986). Great Speeches, vol I. Indiana: Greenwood.

Sanger, D. E. (2001, January 20). Momentous Challenges as Bush Reaches for 12 Minutes of Inaugural Fame. USA: The New York Times.

Suriano, G.R. (1993). Great American Speeches. New York: Random House.

Toolin, C. (1983, Sep.). American Civil Religion from 1789 to 1981: a Content Analysis of Presidential Inaugural Addresses. Review of Religious Research. 25 (1), 39-48.

Woll, P. (2004). American Government. New York: Pearso.

Woronoff, K. (ed). (2002). America's Inaugural: The Speeches, The Presidents, and Their Times. San Diego: Blackbirch Press.

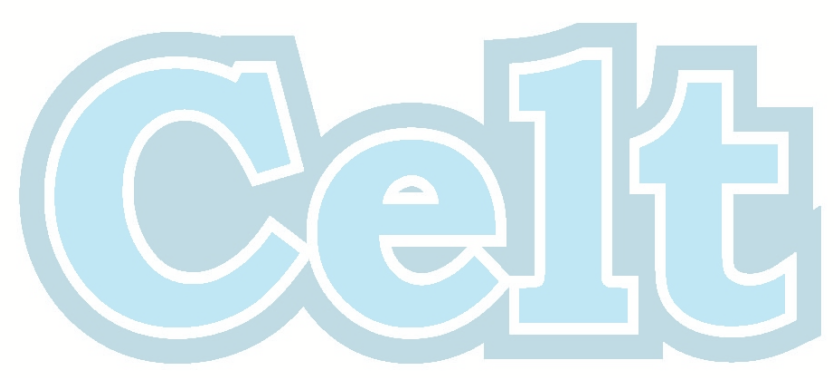

